p-ISSN. 2086-9029

e-ISSN. 2654-5675

Vol. 21 No. 1, HIm. 1-124, Juni 2019

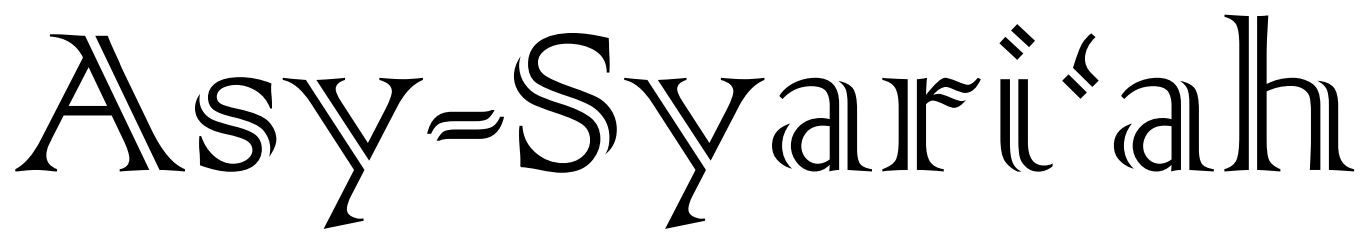

- Islam Nusantara's Perspective on Justice in Polygamy

Beni Ahmad Saebani

- Konstruksi Wakaf Secara Fikih

$(17-30)$ Jaenudin

- Pendekatan Maqashid Syari'ah dalam Praktik Pembiayaan di Koperasi Peternak Sapi Bandung Utara (KPSBU) Lembang Ade Iskandar Nasution

- Kaidah-Kaidah Islam Menjawab Permasalahan Sosial dan Ekonomi Umat

Neneng Hasanah dan Hamzah

- Inovasi Penyaluran Dana Zakat Pada Program Pemberdayaan di Lembaga Amil Zakat

Iw an Setiawan

- Perspektif Siyasah Dusturiyah atas Hak Politik Perempuan dalam Musrembang Kota Bogor

Erma Yulianis

- $\quad$ SBSN PBS, dan SUKRI sebagai Instrumen Pemerintah dalam

Pembiayaan APBN dan Investasi Masyarakat

Suteja Wira Dana Kusuma \& Nisa Dely Amalia

- Partisipasi Politik Kaum Perempuan berdasarkan Pandangan

Fatima Mernissi dan Yusuf Qardhawi

Gayatri Belina Jourdy

FACULTY OF SHARIA AND LAW

STATE ISLAMIC UNIVERSITY SUNAN GUNUNG DJATI BANDUNG-INDONESIA IN COLLABORATION WITH ASOSIASI SARJANA SYARIAH INDONESIA 


\section{Asy-Syari'ah}

\section{Volume 21, Number 1, 2019}

\section{EDITOR-IN-CHIEF}

Ine Fauzia

\section{EDITORIAL BOARD}

Sofyan al-Hakim, UIN Sunan Gunung Djati Bandung, Indonesia Deni Kamaludin Yusup, UIN Sunan Gunung Djati Bandung, Indonesia Meria Utama, Fakultas Hukum Univrsitas Sriwijaya, Indonesia Dewi Mayaningsih, UIN Sunan Gunung Djati Bandung, Indonesia Andrey Sujatmiko, Fakultas Hukum Universitas Trisakti, Jakarta, Indonesia Hetty Hassanah, Universitas Komputer Indonesia, Indonesia

\section{PEER-REVIEWERS}

Muhammad Irfan Helmy, IAIN Salatiga, Semarang, Indonesia Ahmad Ali Nurdin, UIN Sunan Gunung Djati Bandung Tajul Arifin, UIN Sunan Gunun Djati Bandung, Indonesia Mohamad Anton Athoillah, UIN Sunan Gunung Djati Bandung, Indonesia Mrs. Renny Supriyatni, Universitas Padjadjaran, Indonesia Ahmad Tholabi Karlie, UIN Syarif Hidayatullah Jakarta, Indonesia Ija Suntana, UIN Sunan Gunung Djati Bandung, Indonesia Zezen Zaenal Mutaqin, University of California, Los Angeles, United States Ahmad Fathonih, UIN Sunan Gunung Djati Bandung, Indonesia Rahman Syamsuddin, Universitas Islam Negeri Alauddin Makassar, Indonesia

\section{PROOFREADER/DESIGN COVER}

Nanang Sungkawa

\section{LAYOUT EDITOR}

Opik Rozikin

Asy-Syari' ah has been accredited based on the determination of Director General of Research and Development Strengthening, Ministry of Research, Technology and Higher Education of Republic of Indonesia, No. 14/E/KPT/2019 (valid until 2023). 


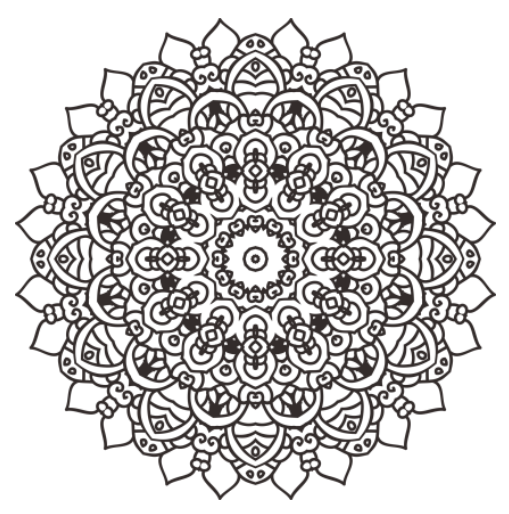

\title{
KONSTRUKSI WAKAF SECARA FIKIH
}

\section{Jaenudin}

Fakultas Syariah dan Hukum UIN Sunan Gunung Djati Bandung

E-mail : jaenudin67@yahoo.co.id

\begin{abstract}
Endowments (waqf) in Islamic law is an importent act, done by wakif as eternal good deeds, to promote economic equality of the people. It has been carried out from the beginning of Islam, being developed up to the present time. By reviewing library materials related to waqf, it was found that waqf law has its own characteristics. Commonly, endowments are binding and should not be traded, but in Hanafi schools of thought, waqf is seen as a ghair lazim contract. Because of its unique and important position, the waqf law needs to be studied thoroughly, and should be designated as special law.
\end{abstract}

Keywords: endowments, fiqh, madzhab. 
Abstraks: Perwakafan dalam hukum Islam merupakan salah satu bagian penting dalam mewujudkan keadilan ekonomi serta amal kebajikan yang terus berlangsung bagi wakif. Wakaf telah dilaksanakan sejak masa Nabi saw dan terus berkembang pada masa sahabat dan generasi setelahnya. Dengan penulusuran bahan pustaka yang terkait permasalahan hukum wakaf, ditemukan bahwa hukum wakaf memiliki ciri tersendiri dari hukum kebendaan (fikih muamalat). Di satu sisi, wakaf bersifat mengikat tidak boleh diperjualbelikan, tetapi pada madzhab Hanafi wakaf dipandang sebagai akad ghair lazim. Kerana kedudukannya yang unik dan penting, hukum wakaf secara fikih dikaji secara menyeluruh, bahkan dalam wakaf juga dilegilasi menjadi hukum yang khusus.

Kata kunci: wakaf, fikih, madzhab. 


\section{Pendahuluan}

Al-Waqf dalam bahasa Arab berarti Al-Habs, yaitu "menahan". ${ }^{1}$ Istilah Waqf (jamaknya: Auqâf) digunakan dalam Hukum Islam sebagai suatu pemilikan dan pemilihan kekayaan tertentu dengan tujuan sosial. ${ }^{2}$ Di Indonesia, istilah al-Waqf atau wakaf dipakai sesuai dengan istilah yang digunakan dalam Fikih dan lebih dikenal dibanding istilah yang lainnya. Istilah Hubus atau Habous adalah istilah wakaf yang digunakan di negeri-negeri muslim lainnya seperti Tunisia, Aljazair dan Maroko. ${ }^{3}$

Secara terminologi, wakaf didefinisikan "Menahan materi benda orang yang berwakaf dan menyedekahkan manfaatnya untuk kebajikan". Mazhab Hanafi berpandangan bahwa status hukum wakaf ghair iltizam yaitu tidak mengikat, artinya wakif dapat saja menarik kembali harta wakafnya. ${ }^{4}$ Akan tetapi, mazhab fiqh selain hanafiah berpendapat bahwa status hukum wakaf itu mengikat (iltizam), artinya harta wakaf tidak dapat ditarik kembali oleh wakif, karena harta wakaf telah menjadi milik umat dan sepenuhnya digunakan untuk kemaslahatan sosial. Argument ini berdasarkan hadis yang diriwayatkan dari Umar Ibn Al-Khattab, yang mana ia telah mewakafkan sebidang tanah di daerah Khaibar untuk kepentingan fakir miskin, kaum kerabat, memerdekakan budak, tamu dan orang terlantar, kemudian disyaratkan pula bahwa wakaf itu tidak boleh dijual, tidak boleh dihibahkan, dan tidak boleh diwariskan. ${ }^{5}$

Penjelasan tersebut mengindikasikan sifat wakaf adalah permanen (muabbad), dengan sifat wakaf seperti itu maka harta yang diwakafkan haruslah bersifat permanen, tidak mudah musnah. Namun dalam perkembangannya harta wakaf tidak hanya harta tidak bergerak seperti tanah juga mencakup harta bergerakseperti uang.

Ameer Ali menjelaskan bahwa institusi wakaf merupakan bagian cabang terpenting dalam sistem hukum Islam, yang menjalin keseluruhan kehidupan agama dan sosial ekonomi umat Islam. ${ }^{6}$ Karena dalam hal ini, wakaf memiliki dua dimensi yang yang sangat jelas yaitu Pertama, berdimensi sosial keagamaan, yang befungsi sebagai penunjang kebutuhan pelayanan sosial yang tidak dibatasi hanya untuk menyantuni fakir miskin dan juga sebagai tujuan dalam pembangunan sarana ibadah, dan Kedua, berdimensi keagamaan, yaitu wakaf yang memiliki tujuan untuk mencapai ridha Allah. Hal ini sesuai dengan Firman Allah dalam OS. Al-Hajj (22) ayat 77, OS. Ali Imran (3) ayat 92, dan Al-Baqarah (2) ayat 261-262.

\footnotetext{
${ }^{1}$ Sayyid Sabiq, Fiqh al-Sunnah, (Bandung: PT. Al-Ma'arif, 1994), hlm. 148.

${ }^{2}$ Monzer Kahf, "Wakaf", dalam John L. Esposito (ed), Ensiklopedi Oxford Dunia Islam Modern, Jilid VI, terj. Eva YN, dkk, (Bandung: Mizan, 2001), hlm. 145.

${ }^{3}$ M. TH. Haoutsma, dkk., First Encyclopaedia of Islam, Vol. VIII, (Leiden: E.J. Brill, 1987), hlm. 1096. lihat juga H.A.R. Gibb dan J.H. Kramers, Shorter Encyclopaedia of Islam, (Leiden: E.J. Brill, 1961), hlm. 624.

${ }^{4}$ Abdul Aziz Dahlan, dkk., "Wakaf", dalam Ensiklopedi Hukum Islam, Jilid VI, (Jakarta: Ichtiar Baru van Hoeve, 1996), hlm. 1905.

${ }^{5}$ lbid.

${ }^{6}$ Asaf A.A. Fyzee, Outlines of Muhammadan Law, (Delhi: Oxford University Press, 1981), hlm. 274.
} 
Sifat lainnya dari institusi wakaf yang pokok adalah sifat yang permanent, kekal, dan tidak dapat hibahkan atau diwariskan, sehingga hak milik wakaf posisinya berada pada Allah semata. Karena sifatnya yang kekal, biasanya wakaf seringkali ditujukkan kepada benda-benda yang bersifat permanen pula, yang pada umumnya ditujukan berupa tanah atau bangunan.?

Karena begitu penting institusi wakaf ini, kemudian para ahli hukum Islam menjelaskan berbagai aturan yang berkait erat dengan wakaf, bahkan pengaturan wakaf di negara-negara muslim sudah melibatkan negara secara langsung dalam pengaturannya, seperti di Indonesia melalui PP No. 28/1977 Tentang Perwakafan Tanah Milik, INPRES No. 1/1991 Buku III Hukum Perwakafan Kompilasi Hukum Islam, UU No. 41/2004 tentang Wakaf, PP No. 42/2006 tentang Pelaksanaan Undang-undang No. 41 Tahun 2004, PP No. 25/2008 tentang Perubahan atas Peraturan Pemerintah No. 42 Tahun 2006, PMA No. 73/2013 tentang Tata Cara Perwakafan Benda Bergerak dan Benda Bergerak Selain Uang, PMA No. 4/2009 tentang Administrasi Pendaftaran Wakaf Uang.

\section{Konstruksi Hukum Wakaf Unsur-unsur Wakaf}

Ali Fikri dalam al-Mu'amalah, menyebutkan bahwa unsur-unsur wakaf meliputi: (1) Wâkif, yakni pihak atau orang yang menyerahkan benda wakaf; (2) Al-'Ain al-Mawqufah, harta benda yang menjadi wakaf; (3) Mawquf 'alaih, yakni pihak yang menerima penyerahan benda wakaf; dan (4) Shigat. ${ }^{8}$

Suparman Usman mencatat setidaknya ada empat unsur dalam wakaf yaitu: pertama, pihak yang mewakafkan (Wâkif). Keduan pihak yang menrima wakaf atau yang diserahi benda wakah atau mauquf alaih. Ketiga benda atau harta yang diwakafkan dan keempat, akad wakaf yaitu sighat ijab Kabul terkait penyerahan dan penerimaan wakaf. ${ }^{9}$ Dalam "Ensiklopedi Hukum Islam", bahwa rukun wakaf mencakup empat rukun yaitu: wakif atau orang yang menyerahkan harta wakaf, harta (mauquf) yang diwakafkan, mauquf alaih atau penerima wakaf, dan sigat akad atau ijab kabul wakaf. Pendapat ini pula yang menjadi pegangan ulama jumhur fuqaha. ${ }^{10}$

Berbeda dengan pendapat jumhur fuqaha, ulama Hanafiah berpendapat bahwa rukun wakaf cukup satu yaitu adanya shigat akad wakaf, yaitu pernyataan dan penerimaan wakaf dengan suatu pernyataan yang jelas menunjukkan kepada akad wakaf. Melalui ijab dan Kabul wakaf maka akad wakaf dengan sendirinya menjadi sah. ${ }^{11}$

\footnotetext{
${ }^{7}$ Ibid., hlm. 274-275.

${ }^{8}$ Ali Fikri, al-Mu'amalah al-Madiyah wa al-Adabiyah, (Mesir: Mustafa al-Bab, 1938), hlm. 307.

${ }^{9}$ Suparman Usman, Hukum Perwakafan di Indonesia, (Jakarta: Darul Ulum Press, 1994), hlm. 32.

${ }^{10}$ Abdul Aziz Dahlan, op. cit., hlm. 1906. Juhaya S. Praja, Perwakafan di Indonesia, (Bandung: Piara, 1997), hlm. 27. Muhammad Daud Ali dan Habibah Daud, Lembaga-lembaga Islam di Indonesia, (Jakarta: RajaGrafindo Persada, 1995), hlm. 270.

${ }^{11}$ Abdul Aziz Dahlan, loc. cit.
} 
Dari unsur-unsur wakaf yang telah disebutkan di atas, pada dasarnya unsur wakaf dalam sudut pandang fikih meliputi empat unsur yaitu: (1) Pihak yang menyerahkan berwakaf (Wâqif); (2) Benda yang diwakafkan (Mauquf bih); (3) Penerima atau yang diserahi wakaf (Mauwquf a'alaih); (4) Shigat atau Ikrar wakaf.

\section{Wâqif atau Wakif (pihak yang menyerahkan wakaf)}

Wakif (yang mewakafkan) memiliki syarat-syarat sebagai berikut ${ }^{12}$ :

Pertama, Ahliyah al-Tabarru' (mempunyai wewenang untuk memberi), yang dimaksud dengan ahli tabarru' adalah orang yang memenuhi syarat-syarat sebagai

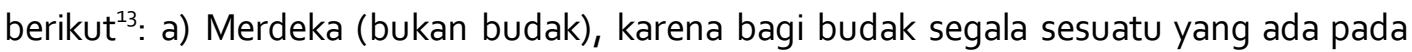
dirinya adalah merupakan milik tuannya. b) Sempurna akalnya. Oleh sebab itu wakaf yang dilakukan oleh orang gila, kesurupan, ataupun mabuk adalah tidak sah. Demikian pula dengan wakafnya orang yang idiot. ${ }^{14} \mathrm{c}$ ) Baligh, yang apabila dibatasi dengan umur adalah mencapai 15 tahun, baik bagi laki-laki maupun perempuan. Sedangkan menurut Qanun Mesir, batasnya adalah 21 tahun, an menurut qanun Suriah batasnya 18 tahun. Dengan demikian, wakaf yang dilakukan oleh anak-anak, baik sudah tamyiz maupun belum, adalah tidak sah. Karena baligh adalah merupakan indikasi dari sempurnanya akal. ${ }^{15}$ d) Bijaksana dalam bertindak (rasyid). Wakaf yang dilakukan oleh orang yang ada di bawah pengampuan, seperti karena pailit, boros maupun pelupa, adalah tidak sah. Meskipun diwakili oleh walinya. Tetapi menurut ulama Hanafiyah, wakafnya orang pailit dan banyak utang adalah sah, namun eksekusi wakafnya tidak bisa dilaksanakan kecuali setelah ada izin dari orang yang mempunyai piutang terhadapnya. Hal tersebut karena tidak ada di bawah pengampuan bukan merupakan syarat sah wakaf, melainkan hanya syarat berlakunya eksekusi terhadap wakaf tersebut. ${ }^{16}$

Mengenai permasalahan wakaf dari orang yang mempunyai utang, terdapat penjelasan sebagai berikut ${ }^{17}$ : (1) Wakaf dari orang yang berpiutang dianggap sah apabila jumlah piutangnya kurang dari jumlah keseluruhan harta miliknya. (2) Jika piutangnya lebih besar dari jumlah hartanya, maka wakafnya baru sah apabila ada izin dari yang memberi piutang, dan gugur jika tidak mendapat izin dari yang memberi piutang. (3) Menurut mazhab Maliki, wakaf dari orang yang memiliki piutang lebih besar dari hartanya dipandang gugur, karena kewajiban membayar piutang lebih utama daripada melaksanakan wakaf.

12 Jalal al-Dien al-Syuyuthy, Syarh al-Tanbih, (Beirut: Dar al-Fikr,1416), II/524. 'Ala al-Dien al-Kasany, Badai' al-Shana'i, (Beirut: al-Maktabah al-'llmiyah, t.th), Vi/218. Jalal al-Dien al-Mahaly, Syarh Minhaj alThalibien, (Indonesia: dar Ihya al-Kutub al-'Arabiyah, t.th), III/97-98. Muhammad Mustafa Syalaby, Muhadharat al-Waqf wa al-Washiyah, (Iskandariyah: Matha'ah Dar al-Ta'lif, 1376), 48.

${ }^{13}$ Syalaby, hlm. 48-50.

${ }^{14}$ Wahbah al-Zuhayly, al-Figh al-Islamy wa Adilatuh, (Damsyk: Dar al-Fikr, 1409), VIII/176.

15 Ibid. 176-177.

${ }^{16}$ Ibid.

${ }^{17}$ Syalaby, $h l m .51-52$. 
e) Bukan orang murtad. Wakaf dari orang yang murtad dianggap batal hal ini berdasarkan pendapat Hanafiah. ${ }^{18}$

Kedua, Mâlik (pemilik barang) secara sah dan sempurna. Wakaf dari barang bukan milik sendiri dipandang batal, ${ }^{19}$ begitu pula wakaf dari hasil ghasab, atau dari hasil transaksi yang fasid. ${ }^{20}$ Begitu pula wakaf dari harta millik umum atau bait al-mal adalah batal. ${ }^{21}$

Ketiga, keinginan sendiri. Orang yang mewakafkan karena paksaan adalah tidak sah, demikian menurut Syafi'iyah dan Malikiyah. ${ }^{22}$

Keempat, dilihat dari tujuan wakafnya seperti untuk masjid, pengadaan al-Quran, bantuan untuk para haji, maka wakif diharuskan beragama Islam, demikian menurut mazhab Hanafiyah dan Malikiyah, ${ }^{23}$ menurut mazhab Syafi'iyah dan Hanabilah tidak disyaratkan harus Islam. ${ }^{24}$

\section{Mauquf bih (harta yang diwakafkan)}

Adapun syarat yang harus dipenuhi oleh mauquf bih adalah sebegai berikut:

Pertama, Harta yang bernilai dan mempunyai nilai manfaat yang positif. Dengan demikian tidak sah mewakafkan setiap barang yang tidak bernilai, tidak memiliki manfaat positif, bahkan mengandung kemadlaratan, seperti barang yang memabukkan, buku-buku yang menyesatkan atau bebau pornagrafi, serta alat-alat hiburan. Karena yang diharapkan dari adanya proses wakaf adalah munculnya manfaat dari barang wakaf serta timbulnya pahala bagi yang mewakafkan.

Kedua, Barang atau harta harus diketahui secara pasti ketika terjadinya proses wakaf, sehingga tidak memungkinkan timbulnya perselisihan mengenai barang atau harta wakaf di kemudian hari.

Ketiga, Barang atau harta tersebut adalah milik sempurna waqif. Dengan demikian menurut jumhur ulama, rahin (yang menggadaikan barang) tidak sah mewakafkan barang gadaian. ${ }^{25}$ Kecuali menurut Hanafiyah, mereka memperbolehkannya karena tidak disyaratkan berang yang hendak diwakafkan harus lepas dari keterikatan dengan orang lain. ${ }^{26}$ Aapun bagi penyewa (musta'jir) dan penibjan (musta'ir) Hanafiyah, Syafi'iyah ddan Hanbilah tidak memperbolehkannya mewakafkan barang sewaan atau pinjaman (barang yang dimilikinya hanya manfaatnya saja, sedangkan dzatiyah barangnya milik orang

\footnotetext{
${ }^{18}$ Zuhayly, hlm. 178.

${ }^{19}$ Syuyuthy, $11 / 524$.

${ }^{20}$ Zuhayly, VIII/176.

${ }^{21}$ Al-Syuyuthy, al-Syaikh al-Syarqawy, al-Syarqawy 'ala al-Tahrir, (Surabaya: Syirkah Bungkul Indah,

${ }^{22}$ Zuhayly, VIII/178.

${ }^{23}$ Ahmad al-Dier Abu al-Barkati, al-Syarh al-Kabier, (Beirut: Dar al-Fikr, t.th), IV/77-79.

${ }^{24}$ Zuhayly, I/184. Barkati, IV/77.

${ }^{25}$ Ibn Qudamah al-Muqaddasy, al-Kafy, (Beirut: al-Maktab al-Islamy, 1408), II/449. Barkati, IV/77.

${ }^{26}$ Zein ibn Muhammad ibn Bakr, al-Bahr al-Ra'iq, (Bairut: Dar al-Ma'rifah,t.th),V/205.
} t.th.), $11 / 174$. 
lain) ${ }^{27}$ kecuali menurut Malikiyah, karena mereka tidak menyaratkan tahan lama ( ta $^{\prime}$ bid) terhadap barang wakaf. ${ }^{28}$ Lain halnya apabila yang mewakafkannya orang yang menyewakan (mu'jir), maka mayoritas ulama memperbolehkannya untuk mewakafkan barang sewaan, kecuali menurut Malikiyah. ${ }^{29}$ Adapun barang wasiat yang pewasiatnya (alMushy) belum meninggal, barang belian atau barang belian yang belum diterima ( $q a b l$ al-qabd), atau barang belian yang masih berada dalam masa khiyar aalah tidak sah untuk diwakafkan. Demikian pula dengan barang yang diperoleh dengan cara pembelian suf'ah, karena meskipun secara zahir, tanah tersebut adalah milik pembeli (syafi'), namun hak membelinya tidak murni, karena ditumpangi dengan hak syuf'ah. ${ }^{30}$

Barang ghasab tidak sah untuk diwakafkan, lain halnya apabila seseorang mewakafkan tanaman yang ditanam di atas tanah hasil ghasab, maka wakaf tersebut sah, kecuali menurut al-Subky dan Ibn Rif'ah. Demikian pula halnya mewakafkan tanaman yang ditanam di atas tanah hasil ghasab..$^{31}$ (1) Barang atau harta tersebut adalah milik pribadi (mufraz) yang tidak bercampur dengan milik orang lain (musytarak/musya), baik memungkinkan untuk dibagi (yuqbal al-qismah) maupun tidak memungkinkan untuk dibagi (la yuqbal al-qismah). Syarat tersebut ditetapkan oleh mayoritas Hanafiyah, ${ }^{32}$ sedangkan Malikiyah membolehkannya selama memungkinkan untuk dibagi (yuqbal alqismah), dan kepada waqif diharuskan memaksa untuk membaginya. ${ }^{33}$ Adapun yang menjadi alasan utamanya adalah, ketika barang tersebut masih bercampur kepemilikannya (musya), maka tidak memungkinkan untuk adanya proses penyerahan dan penerimaan wakaf (taslim wa taqbid atau tahwiz) adalah merupakan syarat sahnya transaksi wakaf. Serta dengan adanya unsur milik orang lain di dalam harta wakaf, hal tersebut akan menjadi motif timbulnya perselisihan di kemudian hari. Kecuali menurut Syafi'iyah, ${ }^{34}$ Hanabilah, ${ }^{35}$ dan Abu Yusuf ${ }^{36}$ dari kalangan Hanafiyah, serta Zhahiriyah. ${ }^{37}$ Mereka menganggap sah terhadap wakaf barang musya', berdasarkan riwayat dari alSyafi'i dari Sufyan dari Abdullah ibn 'Umaribn Hafsin dari Nafi' dari Abdullah Ibn 'Umar, yang menyatakan bahwa Umaribn Khatab mewakafkan seratus sahamnya di tanah Khaibar. ${ }^{38}$

\footnotetext{
${ }^{27}$ Abu Hamid al-Ghazali, al-Wasith, (Kairo: Dar al-Salam, 1417), IV/240. Qalyuby, III/oo.

${ }^{28}$ Barkati, IV/77.

${ }^{29}$ Zuhayly, VIII/168.

${ }^{30}$ Syalaby, 55-57.

${ }^{31}$ Qalyuby.

${ }^{32}$ Kasany, $\mathrm{Vl} / 220$.

${ }^{33}$ Barkati, IV/76.

${ }^{34}$ Ghazaly, IV/239. Syarqawy, II/177.

${ }^{35}$ Ibn Qudamah, II/448.

${ }^{36}$ Kasany, Abu Husain al-Maedhiyany, al-Hidayah Syarh al-Bidayah, (Beirut: al-Maktabah al-

${ }^{37}$ Muhammad Ibn Hazm, al-Muhalla, (Beirut:Dar al-Fikr, t.th), IX/182.

${ }^{38}$ Zuhayly, VIII/185-186.
} Islamiyah, t.th), III/448 
(2) Barang harus dapat diambil manfaatnya secara lama tanpa merusak dzatiyah barang. ${ }^{39}$ Dengan demikian, tidak sah mewakafkan makanan, minuman atau minyak wangi, kecuali menurut Malikiyah. ${ }^{40}$ (3) Barang tersebut harus barang tak bergerak, seperti tanah. Dengan demikian tidak sah mewakafkan kendaraan, alat-alat perkerjaan, buku dan lain-lain. Hanya Hanafiyah yag menetapkan syarat tersebut dengan alasan bahwa barang wakaf haruslah abadi, sementara barang begerak, seperti mewakafkan ladang beserta sapi berikut alat-alat bajaknya. ${ }^{41}$ Sedangkan mayoritas ulama (Malikiyah, Syafi'iyah dan Hanabilah), termasuk Zhahiriyah ${ }^{42}$ memperbolehkan mewakafkan barang bergerak, seperti kendaraan, pedang atau baju besi. (4) Barang yang hendak diwakafkan bukan merupakan barang yang dilarang memilikinya, seperti anjing atau babi. ${ }^{43}$ Namun khusus untuk wakaf anjing (penjaga atau pemburu) ulama Syafi'iyah memperselisihkannya, karena di dalamnya terkandung unsur positif yang dapat diambil. ${ }^{44}$

\section{Mauquf 'alaih (penerima atau yang diserahi wakaf)}

Mauquf 'alaih terdiri atas dua bagian, yaitu jihat wakaf yang tetentu (mu'ayyan) seperti kepada A, B, C, atau D. dan jihat wakaf yang tidak tertentu (ghair mu'ayyan), seperti ulama, mujahid, fakir miskin, masjid.

Adapun syarat yang telah disepakati oleh seluruh ulama mazhab bagi mauquf 'alaih atau jihat wakaf yang tetentu (mu'ayyan) adalah mauquf 'alaih harus merupakan orang atau badan yang dapat diakui kepemilikannya. Adapun syarat-syarat yang diperselisihkan antara lain:

Pertama, menurut Hanafiyah, mauquf 'alaih dapat terdiri dari orang atau badan yang ada serta diketahui keberadaannya, muslim, kafir dzimmy, majusy (karena majusy bagian dari ahl dzimmah). Dengan demikian, tidak sah wakaf kepada kafir harby, untuk pembangunan gereja atau sinagog. Menurut Abu Yusuf, sah wakaf kepada diri sendiri, sementara menurut Abu Hanifah dan Muhammad, wakaf tersebut adalah tidak sah, kecuali apabila yang diperuntukkan bagi diri sendirinya itu hanylah hasilnya saja. ${ }^{45}$

Kedua, menurut Malikiyah, mauquf'alaih harus kepada orang atau badan yang ada, baik diketahui maupun tidak diketahui, walaupun jauh atau kepada orang yang belum ada, seperti janin yang akan lahir. Apabila janin tersebut mati atau atau sebelum janin lahir muncul mani' (waqif lebih dulu mati atau sakit yang sudah tidak ada harapan), maka hasil (ghullah) dari barang wakaf tersebut diserahkan kepada waqif atau kepada keturunannya (apabila waqif telah mati). Dengan demikian bagi waqif berhak untuk

\footnotetext{
${ }^{39}$ Ibn Qudamah, IV/449.

${ }^{40}$ Barkati, IV/77.

${ }^{41}$ Kasany, $\mathrm{VI} / 220$

$4^{2}$ Ibn Hzam, IX/175.

43 Zuhayly, VIII/188.

${ }^{44}$ Ghazaly, IV/240.

${ }^{45}$ Al-Marghiyany, III/17-18.
} 
menjual barang wakaf selama janin belum lahir. Sah wakaf kepada orang miskin ataupun kepada orang kaya asalkan bukan kafir harby. Tetapi apabila kepada binatang, maka hukumnya tidak sah.

Ketiga, menurut Syafi'iyah, mauquf 'alaih tidak boleh putus di awal (munqathi' alawwal), yaitu orang atau badan yang tidak atau belum ada pada waktu proses terjadi. Dengan demikian tidak sah wakaf kepada orang atau badan yang belum ada, seperti kepada janin atau keperluan masjid yang belum dibangun. Apabila mauquf 'alaih-nya putus di akhir (munqathi' al-akhir), seperti wakaf kepada anak-anaknya atau kepada orang lain, tanpa disebutkan selanjutnya untuk siapa, maka hukum wakafnya sah, kecuali menurut al- Ghazali, ${ }^{46}$ serta penerima selanjutnya setelah anak-anaknya mati adalah kepada kerabat yang paling dekat hubugan keluarganya. ${ }^{47}$ Demikian pula menurut Ibn Hazm, berdasarkan riwayat wakafnya Abu Thalhah. ${ }^{48}$ Tidak sah wakaf kepada binatang, ${ }^{49}$ kecuali binatang yag diwakafkan seperti dipergunakan dalam perang. ${ }^{50}$

Di antara syarat mauquf 'alaih yang lainnya adalah bukan budak, muslim baik miskin maupun kaya (menurut al-Ghazali, wakaf kepada orang kaya tidak menghasilkan pahala bagi waqif), serta kafir dzimmy. Dengan demikian tidak sah wakaf kepada kafir harby atau kepada orang murtad. ${ }^{51}$

Syafi'iyah menganggap tidak sah terhadap wakaf yang diperuntukkan bagi dirinya sendiri (waqif) atau disyaratkan bahwa waqif akan ikut menggunakan manfaatnya. Namun ada sebagian ulama Syafi'iyyah memperbolehkan syarat tersebut seperti Abu Abdullah al-Zabidy. ${ }^{52}$

Keempat, Syarat mauquf 'alaih yang ditetapkan oleh Hanbilah secara global sama dengan syarat yang ditetapkan Syafi'iyah. Kecuali dalam masalah wakaf kepada janin, kalau menurut Syafi'iyah janin tidak berhak atas barang wakaf secara mutlak, maka menurut Hanbaliyah, janin dapat menerima wakaf hanya apabila bukan sebagai penerima yang pertama. ${ }^{53}$ Serta menurut mereka tidak sah wakaf kepada orang kaya. ${ }^{54}$

Kelima, adapun wakaf yang tidak tertentu, seperti wakaf kepada manusia: fakir miskin, ulama, pelajar, kerabat, atau kepada selain manusia: masjid, rumah sakit, panti jompo. Syaratnya harus diketahui keberadaannya serta mengandung kebajikan. Menurut Hanabilah, tidak sah wakaf pada jihat yang hanya mengandung kemubahan, seperti

\footnotetext{
${ }^{46}$ Ghazaly, IV/246.

${ }^{47}$ Syarqawy, II/174.

${ }^{48}$ Ibn Hazm, IX/183.

${ }^{49}$ Ghazaly, IV/242.

${ }^{50}$ Syarqawy, II/176.

${ }^{51}$ Ghazaly, IV/241.

${ }^{52}$ Ghazaly, IV/243.

53 Ibn Qudamah, II/449.

54 Zuhayly, VIII/195.
} 
kepada siswa yang mempeljari syair. Apalagi yang mengandung hal-hal yang dimakruhkan, seperti kepda siswa yang mempelajari ilmu filsafat. ${ }^{55}$

\section{Shigat atau Ikrar Wakaf}

Seluruh ulama mazhab menyepakati bahwa shigat yang menjadi rukun wakaf adalah hanyalah ljab saja, adanya Oabul bukanlah bagian dari rukun. ${ }^{56}$ Kecuali dalam wakaf kepada orang atau badan yang tertentu (muayyan), maka Malikiyah, Syafi'iyah dan sebagian Hanabilah menyaratkan harus adanya qabul dari pihak mauquf 'alaih. ${ }^{57}$

Yang dimaksud ljab adalah ucapan dari waqif yang menunjukkan kehendak atau keinginan atas mewakafkan sesuatu. Adapun syarat-syarat untuk sahnya sebuat shigat adalah: Pertama, Harus Tanjiez (dapat dilaksanakan seketika), dengan kata lain tidak boleh dikaitkan dengan sesuatu yang belum ada /terjadi pada waktu proses..$^{88}$

Kedua, Tidak boleh disertai dengan syarat bathil, seperti wakaf tersebut dikemudian hari akan dijual atau ditarik kembali. ${ }^{59}$

Ketiga, Tidak boleh dibatasi dengan waktu (ta'qiet). Kecuali menurut Malikiyah, karena menurut mereka, wakaf tidak disyaratkan harus abadi. ${ }^{60}$ Wakaf yang dibatasi dengan waktu, menurut al-Ghazali, apabila dalam wakafnya terdapat unsur "tahrir", seperti tanah dijadikan masjid, maka syarat (batasan waktu) tersebut batal, sementara wakafnya adalah sah. Lain halnya apabila tidak terdapat unsur "tahrir", seperti wakaf tanah untuk seseorang, maka syarat berikut wakafnya adalah batal. ${ }^{61}$

Keempat, Menyebutkan arah penyalurannya atau mauquf 'alaih-nya secara jelas. Adapun yang menetapkan syarat tersebut adalah hanya Syafi'iyah. Dengan demikian apabila seseorang mewakafkan tanahnya dengan kalimat, "Aku wakafkan tanah ini", tanpa menyebutkan arah penyalurannya, maka wakafnya tidak sah. Kecuali menurut pendapat kedua dinyatakan bahwa wakaf tersebut sah, dan yang berhak atas tanah wakaf tersebut adlah kerabat dekat waqif, sebagaimana dalam kasus mauquf 'alaih mun-

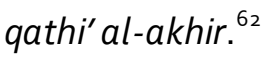

\section{Bentuk-bentuk Wakaf}

Dalam sejarah Islam periode pertama dikenal berbagai bentuk wakaf, Pertama, bentuk wakaf keagamaan, dalam hal ini Masjid Quba di Madinah, merupakan bentuk wakaf keagamaan yang pertama. Mesjid ini dibangun tahun 622 ketika Nabi saw hijrah

\footnotetext{
${ }^{55} \mathrm{lbid}$.

${ }^{56}$ Syalaby, 67.

${ }^{57}$ Ghazaly, IV/245. Nawawy, III/101. Barkaty, IV/88.

${ }^{8}$ Syalaby.

${ }^{59}$ Syalaby, 69 .

${ }^{60}$ Ibid., 70.

${ }^{61}$ Ghazaly, IV/247.

${ }^{62}$ Ibid., IV/250.
} 
dan tiba di Quba. Setlah pembangunan Mesjid Quba, dibangun pula mesjid Nabawi di kota Madinah. $^{63}$

Bentuk kedua wakaf adalah wakaf kebaikan untuk kemanusiaan (filantropis). Tujuan wakaf filantropis ini untuk tujuan yang lebih luas seperti menyantuni anak yatim serta fakir miskin, mendanai lembaga dan aktivitas seperti perpustakaan, riset keilmuan, pendidikan, pelayanan kesehatan, pemeliharaan binatang, dan lingkungan hidup. Wakaf dapat juga digunakan untuk pinjaman usaha kecil, pembangunan dan pemeliharaan taman, jalan raya, jembatan, dan bendungan. Wakaf derma (filantropis) ini dimulai pada masa Nabi Saw. Saat itu Mukhairiq berkehendak mewakafkan tujuh bidang kebun miliknya yang ada di Madinah setelah dia wafat kepada Nabi Saw. Setelah Mukhairiq meninggal dunia Pada 626, kemudian Nabi saw mengambil tanah tersebut sebagai tanah wakaf yang pemanfaatannya untuk fakir miskin. Praktek ini diikuti oleh para sahabat Nabi, seperti Umar Ibn Khattab, yang mewakafkan tanahnya di Khaibar untuk keperluan fakir miskin. ${ }^{64}$

Bentuk wakaf ketiga terjadi pada masa khilafah Umar ibn Khatab di tahun 635-645. Khalifah Umar menjadikan tanah wakafnya di khiabar secara tertulis dan disaksiskan oleh para sahabat. Jabir, sahabat yang lain, mengatakan bahwa ketika dokumen tersebut diwujudkan, banyak pemilik tanah yang banyak memberikan wakaf. Beberapa di antara mereka menambahkan persyaratan wakaf, bahwa hasil dari buah-buahan dan manfaat yang diperoleh dari tanah wakaf pertama kali kepada anak-anak, serta ahli waris mereka, dan hanya apabila ada lebihnya, diberikan kepada fakir miskin. Wakaf jenis ini disebut sebagai wakaf keluarga. ${ }^{65}$

Menurut Ameer Ali, pemanfaatan hasil wakaf dapat ditujukan kepada tiga kelompok utama. Pertama, hasil wakaf dapat digunakan oleh semua orang tanpa kecuali seperti wakaf sekolah atau rumah sakit. Kedua, pemanfaatn wakaf yang ditujukan untuk keluarga. Ketiga, wakaf yang diperuntukkan khusus bagi fakir miskin ${ }^{66}$

Kemudian para fuqaha membagi wakaf yang dikaitkan dengan pihak penerima wakaf dibagi menjadi dua, pertama, wakaf ahli, dan kedua, wakaf khairi. ${ }^{67}$ Wakaf ahli ialah wakaf yang pemanfatannyauntuk orang-orang tertentu yang umumnya terdiri atas keluarga atau anggota keluarga dan keturunan wakif. Oleh karena itu, wakaf jenis ini seringkali disebut wakaf dzurry yang berarti wakaf untuk sanak keluarga. Wakaf ahli ini secara hukum benar dan pernahterjadi pada masa Nabi Saw, yaitu ketika Abu Thalhah mewakafkan sebidang kebun kepada keluarganya. Peristiwa ini tercatat dalam hadits yang diriwayatkan Bukhari dan Muslim dari Anas ibn Malik:

\footnotetext{
${ }^{63}$ Monzer Kahf, hlm. 146.

${ }^{64} \mathrm{lbid}$

${ }^{6} \mathrm{lbid}$.

${ }^{66}$ Asaf A.A. Fyzee, hlm. 282.

${ }^{67}$ Ali Fikri, hlm. 317. dan Juhaya S. Paraja, hlm. 30-31.
} 


$$
\begin{aligned}
& \text { عن أنس رضى الله عنه قال : كان أبو طلحة أكثر أنصارى بالمدينة مالا, وكان أحب أمواله إليه بيرحاء. وكانت }
\end{aligned}
$$

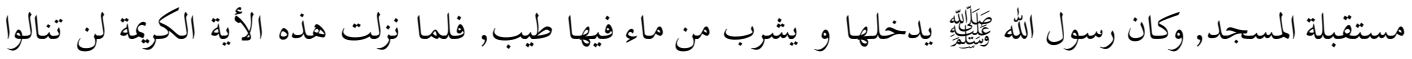

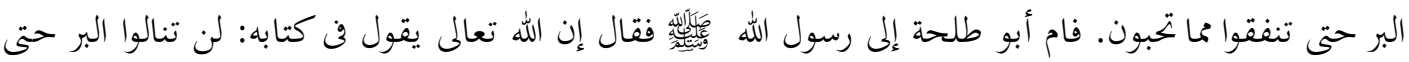

$$
\begin{aligned}
& \text { تنفقوا محا تحبون. وإن أحب أموالم بيرحاء, و إذها صدقة لله أرجوا برها وذخرها عند الله فضعها يارسول الله حيث }
\end{aligned}
$$

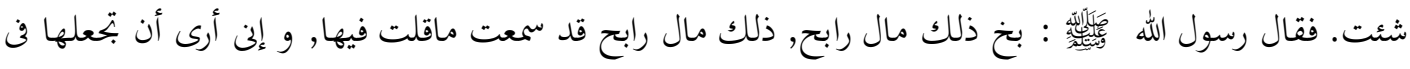

$$
\begin{aligned}
& \text { الأقربين, فقسمها أبو طلحة في أقلربه وبنى عمه. }
\end{aligned}
$$

"Dari Anas berkata: Abu Thalhah, sahabat Ansor yang kaya di Madinah. Dan satusatunya harta yang paling dicintainya adalah "Bairaha" (sebidang kebun kurma dekat masjid Nabawi) yang menghadap ke masjid. Rasulullah saw memasuki dan meminum air di dalamnya yang baik itu. Ketika ayat al-Quran, "lan tanalul birra hatta tunfiqu mimma tuhibbun (kamu sekali-kali tidak akan memperoleh kebaikan sehingga kamu menginfakkan sebagian harta yang kamu cintai)" turun, Abu Thalhal menghadap kepada Rasulullah Saw seraya berkata: "Sesungguhnya Allah telah berfirman dalam kitabNya: "lan tanalul birra hatta tunfiqu mimma tuhibbun (kamu sekali-kali tidak akan memperoleh kebaikan sehingga kamu menginfakkan sebagian harta yang kamu cintai)", dan sungguh harta yang paling aku kucintai adalah "Bairaha", dan ia akan kujadikan shadaqah karena Allah yang aku harapkan hanya kebaikannya dan simpanlah di sisi Allah; maka tentukanlah sedekah itu sebagaimana engkau sukai wahai Rasulullah". Rasulullah Saw berkata: "Bukan main itulah harta yang paling menguntngkan, itulah harta yag paling menguntungkan. Aku telah mendengar apa yang engkau katakan mengenai "Bairaha" itu. Sesungguhnya aku berpendapat agar kamu menjadikannya sebagai sedekah bagi para keluarga". Lalu Abu Thalhah membagikannya untuk para keluarga dan anak-anak pamanya".

Wakaf ahli berakhir jika sudah tidak ada lagi keluarga yang memanfaatkan wakaf tersebut dan dapat berubah menjadi wakaf khairi, yakni wakaf yang ditujukan untuk kepentingan umum.

Wakaf khairi ialah suatu bentuk wakaf yang dinyatakan oleh wakif untuk tujuan umum (li mashâlih al-ummat). Wakaf khairi dapat jga semula berstatus wakaf ahli. Penerima wakaf khairi boleh orang bukan Muslim sepanjang ia tidak memusuhi Islam, seperti yang dimaksud al-Quran surat al-Mumtahanah (60) ayat 8 :

لا ينها كم الله عن الذين لم يقاتلوكم فن الدين ولم يخرجوكم من دياركم أن تبروهم وتقسطوا إليهم إن الله يحب

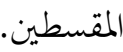

"Allah tidak melarang kamu untuk berbuat baik dan berlaku adil kepada orangorang yang tidak memerangi kamu lantaran soal agama dan tidak pula mengusir kamu dari negerimu. Sesungguhnya Allah menyukai orang-orang yang berlaku adil". 
Kemudian hadits tentang wakaf Umar ibn Khattab atas sebidang tanah di Khaibar, juga menunjukkan jenis wakaf khairi. Hadis tersebut diriwayatkan oleh Imam Bukhari dari Ibn Umar.

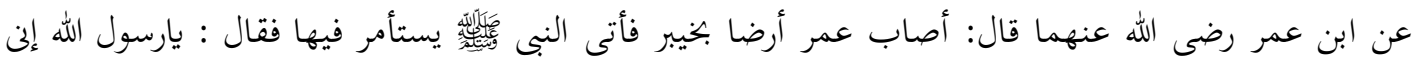

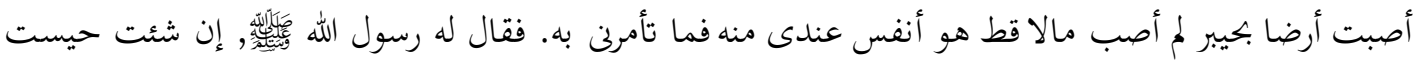

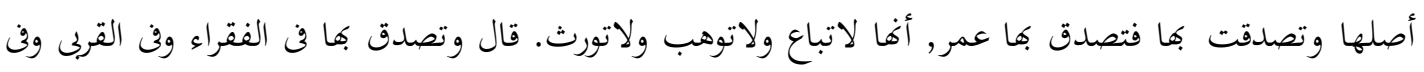

$$
\begin{aligned}
& \text { الرقاب وفى سبيل الله وابن السبيل والضيف لاجناح على من وليها أن يأكل منها بالمعروف ويطعم غير متموّل. }
\end{aligned}
$$

"Dari Ibn Umar berkata, bahwa Umar memperoleh sebidang tanah di Khaibar, kemudian menghadap Rasulullah Saw untuk memohon petunjuk. Umar berkata: "Ya, Rasulallah, saya mendapatkan sebidang tanah di Khaibar, saya belum pernah mendapatkan harta sebaik itu, maka apakah yang engkau perintahkan kepadaku?" Rasulullah Saw bersabda: "Bila kamu suka, kamu tahan (pokok) tanah itu, dan kamu sedakahkan manfaatnya". Kemudian Umarpun menyedekahkan manfaatnya, dengan syarat tanah itu tidak akan dijual, tidak diberikan dan tidak diwariskan. Tanah itu ia wakafkan kepada orang-orang fakir, para keluarga, memerdekakan hamba sahaya, sabilillah, ibnu sabil dan tamu. Dan tidak ada halangn bagi orang yang mengurusnya untuk memakannya dengan cara yang baik, tanpa bermaksud memiliki harta tersebut".

Menurut jumhur fuqaha, dalam penyelenggaraan wakaf khairi ditunjuk nazir oleh wakif yang bertugas untuk mengurus dan mengawasi harta wakaf khairi tersebut. Atau melalui pengadilan, dimana hakim dapat menunjuk nazir wakaf. Pada saat ini di Indonesia berkembang wakaf produktif sebagai pembumian hukum mengenai wakaf sehingga dapat memberikan manfaat langsung secara ekonomi bagi umat. ${ }^{68}$

\section{Kesimpulan}

Dari hasil pembahasan terhadap di atas, dapat disimpulkan bahwa dari bebarapa pandangan mengenai unsur-unsur wakaf terutama dari sudut hukum Islam, dapat disimpulkan bahwa unsur-unsur wakaf pada intinya meliputi: (1) Wakif atau Waqîf (pihak yang menyerahkan berwakaf); (2) Mauquf bih (harta yang diwakafkan); (3) Mauwquf a'alaih (penerima atau yang diserahi wakaf); (4) Shigat atau Ikrar wakaf. Adapun dalam aturan hukum Indonesia yang terhimpun dalam Peraturan Pemerintah No. 28 Tahun 1977 tentang Perwakafan Tanah Milik dan Inpres No. 1 Tahun 1991 Kompilasi Hukum Islam pada Buku III tentang Perwakafan, unsur unsur wakaf meliputi: (1) Wakif, badan-badan hukum Indonesia dan orang; (2) Tanah atau benda milik yang akan diwakafkan, benda wakaf tersebut harus bebas dari segala pembebanan, ikatan, sitaan dan perkara; (3) Ikrar wakaf; (4) Nadzir; (5) Pejabat Pembuat Akata Ikrar Wakaf (PPAIW); (6) Saksi, sekurangkurangnya 2 orang saksi.

${ }^{68}$ Neneng Hasanah, Kontekstualitas Ayat-Ayat Hukum Wakaf di Indonesia, Asy-Syari'ah Volume 20 Edisi 2, Hlm. 133-144 
Di samping itu, bentuk wakaf menurut para fuqaha terbagi kepada dua bagian, yaitu: Pertama, Wakaf Ahli atau Wakaf Dzurri yaitu wakaf yang hasilnya diperuntukkan bagi orang-orang tertentu yang umumnya terdiri atas keluarga atau anggota keluarga dan keturunan wakif. Kedua, Wakaf khairi ialah suatu bentuk wakaf yang diikrarkan oleh wakif untuk tujuan umum (li mashâlih al-ummat), seperti unatuk para fakir miskin, ibnu sabil, sabilillah dan sebagainya.

\section{DAFTAR PUSTAKA}

'Ala al-Dien al-Kasany, Badai' al-Shana'i, Beirut: al-Maktabah al-'Ilmiyah, t.th.

Abdul Aziz Dahlan, dkk., "Wakaf", dalam EnsiklopediHukum Islam, Jilid VI, Jakarta: Ichtiar Baru van Hoeve, 1996.

Abu Hamid al-Ghazali, al-Wasith, Kairo: Dar al-Salam, 1417.

Abu Husain al-Maedhiyany, al-Hidayah Syarh al-Bidayah, Beirut: al-Maktabah alIslamiyah, t.th.

Ahmad al-Dier Abu al-Barkati, al-Syarh al-Kabier, Beirut: Dar al-Fikr, t.th.

Ali Fikri, al-Mu'amalah al-Madiyah wa al-Adabiyah, Mesir: Mustafa al-Bab, 19387.

al-Syaikh al-Syarqawy, al-Syarqawy 'alaal-Tahrir, Surabaya: Syirkah Bungkul Indah, t.th. Amirah, Hasyiyah Qalyuby wa 'Amirah, Indonesia: Maktabu Dar al-Ihya, t.th.

Asaf A.A. Fyzee, Outlines of Muhammadan Law, Delhi: Oxford University Press, 1981.

H.A.R. Gibb dan J.H. Kramers, Shorter Encyclopaedia of Islam, Leiden: E.J. Brill, 1961.

Ibn Qudamah al-Muqaddasy, al-Kafy, Beirut: al-Maktab al-Islamy, 1408.

Jalal al-Dien al-Mahaly, Syarh Minhaj al-Thalibien, Indonesia: dar Ihya al-Kutub al'Arabiyah, t.th.

Jalal al-Dien al-Syuyuthy, Syarh al-Tanbih, Beirut: Dar al-Fikr,1416.

Juhaya S. Praja, Perwakafan di Indonesia, Bandung: Piara, 1997.

M. TH. Haoutsma, dkk., First Encyclopaedia of Islam, Vol. VIII, Leiden: E.J. Brill, 1987.

Monzer Kahf, "Wakaf", dalam John L. Esposito (ed), Ensiklopedi Oxford Dunia Islam Modern, Jilid VI, terj. Eva YN, dkk, (Bandung: Mizan, 2001.

Muhammad Daud Ali dan Habibah Daud, Lembaga-lembaga Islam di Indonesia, Jakarta:

RajaGrafindo Persada, 1995.

Muhammad Ibn Hazm, al-Muhalla, Beirut:Dar al-Fikr, t.th.

Muhammad Mustafa Syalaby, Muhadharat al-Waqf wa al-Washiyah, Iskandariyah: Matha'ah Dar al- Ta'lif, 1376.

Neneng Hasanah, Kontekstualitas Ayat-Ayat Hukum Wakaf di Indonesia, Asy-Syari'ah

Volume 20 Edisi 2, HIm. 133-144

Sayyid Sabiq, Figh al-Sunnah, Bandung: PT. Al-Ma'arif, 1994.

Suparman Usman, Hukum Perwakafan di Indonesia, Jakarta: Darul Ulum Press, 1994.

Wahbah al-Zuhayly, al-Figh al-Islamy wa Adilatuh, Damsyk: Dar al-Fikr, 1409.

Zein ibn Muhammad ibn Bakr, al-Bahr al-Ra'iq, Bairut: Dar al-Ma'rifah,t.th. 
Asy-Syari'ah (P-ISSN : 2086-9029 E-ISSN: 2654-5675) is a periodical scientific journal that publishes various results of studies and research, literature review, and other scientific works whose scope covers the field of Islamic law/sharia, law and society in monodisciplinary, interdisciplinary, and multidisciplinary manners. The journal aims to expand and create innovative concepts, theories, paradigms, perspectives and methodologies in the above said scope. The Journal is published twice a year (june and december) by Faculty of Shariah and Law, Sunan Gunung Djati State Islamic University Bandung in collaboration with Asosiasi Sarjana Syariah Indonesia (ASSYI).

\section{EDITORIAL OFFICE:}

Fakultas Syariah dan Hukum UIN Sunan Gunung Djati Bandung Jl. Raya A.H. Nasution No. 105 Cibiru Kota Bandung, 40614

Tlp/Fax: +022-7802278 Faks. 022-7802278

Website http://journal.uinsgd.ac.id/index.php/asy-syariah/index

E-mail: Jurnalasy-syariah@uinsgd.ac.id 